\title{
MODAL KERJA, SIZE, STRUKTUR MODAL DAN RETURN ON ASSET: STUDI EMPIRIS PERUSAHAAN MANUFAKTUR YANG TERDAFTAR DI BEI
}

\author{
Fransiskus Rian \\ Gendro Wiyono \\ Mujino \\ Program Studi Manajemen Fakultas Ekonomi \\ Universitas Sarjanawiyata Tamansiswa \\ Jalan Kusumanegara, Yogyakarta, 55165 \\ Telepon +62 (274)562265, Fax. +62 (274) 547042 \\ Email korespondensi: fransiskusrian123@gmail.com
}

\begin{abstract}
The purpose of this study is to examine whether working capital variables, size, and capital structure affect the return on assets. The population in this study are manufacturing companies in various subsectors proposed in the Indonesia stock exchange in 2016-2018. The type of data used in this study is secondary data from the company's annual financial statements as a sample that is used and processed using SPSS 16.00. This research uses the classic assumption test and the data analysis method used is multiple linear regression analysis. The results of the study show how working capital (ratio using current ratio, accounts receivable turnover, and net working capital), size, and capital structure (tested using a debt to equity ratio) are considered to compare asset returns.
\end{abstract}

Keywords: working capital, size, capital structure, return on assets

\begin{abstract}
ABSTRAK
Tujuan dari penelitian ini adalah untuk menguji apakah variabel modal kerja, ukuran, dan struktur modal berpengaruh terhadap return on assets. Populasi dalam penelitian ini adalah perusahaan manufaktur di berbagai sub sektor yang diusulkan di Bursa Efek Indonesia tahun 2016-2018. Jenis data yang digunakan dalam penelitian ini adalah data sekunder berupa laporan keuangan tahunan perusahaan sebagai sampel yang digunakan dan diolah menggunakan SPSS 16.00. Penelitian ini menggunakan uji asumsi klasik dan metode analisis data yang digunakan adalah analisis regresi linier berganda. Hasil penelitian menunjukkan bagaimana modal kerja (rasio menggunakan rasio lancar, perputaran piutang, dan modal kerja bersih), ukuran, dan struktur modal (diuji menggunakan rasio utang terhadap ekuitas) dipertimbangkan untuk membandingkan pengembalian aset.
\end{abstract}

Kata kunci: modal kerja, ukuran, struktur modal, return on assets 


\section{PENDAHULUAN}

Setiap aktivitas yang dilaksanakan oleh setiap perusahaan selalu memerlukan dana, baik digunakan untuk membiayai kegiatan operasional sehari-hari maupun untuk membiayai untuk membiayai investasi jangka panjangnya (Susilowibowo, Rahayu dan Joni, 2014). Dana yang digunakan untuk melangsungkan kegiatan operasional seharihari disebut modal kerja. Modal kerja yang dibutuhkan oleh setiap perusahaan untuk membiayai kegiatan operasinya sehari-hari, dimana modal kerja yang telah dikeluarkan itu diharapkan akan dapat kembali lagi masuk dalam perusahaan pada jangka waktu yang pendek melalui hasil penjualan produksinya (Susilowibowo, Rahayu dan Joni, 2014).

Selain dari modal kerja, variabel berikutnya dalam penelitian ini adalah size. Ukuran perusahaan menurut Widjadja (2009) adalah suatu ukuran yang menunjukkan besar kecilnya suatu perusahaan. Ukuran perusahaaan dapat diukur dengan antara lain total penjualan, rata-rata tingkat penjualan, dan total aktiva. Pada umumnya, perusahaan besar yang memiliki total aktiva yang besar mampu menghasilkan laba yang besar. Perusahaan yang memiliki total asset yang besar telah mencapai tahap kedewasaan, dimana dalam tahap ini arus kas perusahaan sudah positif dan dianggap memiliki prospek yang baik dalam jangka waktu yang relatif lebih stabil dan lebih mampu menghasilkan laba dibanding perusahaan dengan total aset yang relatif kecil (Najoan, 2016). Besar kecilnya perusahaan dapat memengaruhi kemampuan dalam menanggung risiko yang mungkin timbul akibat berbagai situasi yang dihadapi perusahaan yang berkaitan dengan operasinya.

Dalam penelitian ini juga menjelaskan tentang struktur modal yang merupakan kombinasi antara hutang dengan modal. Hutang terdiri utang jangka panjang dan hutang jangka pendek. Hutang dan modal sendiri digunakan untuk membelanjai aktiva-aktiva yang dimiliki oleh perusahaan. Menurut Novita, Asri, dan Sofie (2015), struktur modal juga merupakan bagian dari sumber pendanaan perusahaan yang dapat diperoleh dari modal ekuitas yang bersifat permanen dan sumber pendanaan jangka pendek bersifat sementara yang memiliki risiko lebih tinggi. Struktur modal adalah pendanaan ekuitas dan hutang pada suatu perusahaan yang sering dihitung berdasarkan besar atau relatifnya sumber pendanaan. Risiko kegagalan untuk melunasi bunga, pokok pinjaman bergantung pada sumber pendanaan serta jenis dan jumlah dari berbagai aset yang dimiliki perusahaan.

Keputusan dalam struktur modal merupakan keputusan yang sangat penting bagi pihak perusahaan. Manajemen perusahaan dapat menentukan apakah akan menggunakan ekuitas atau hutang jangka panjang dalam mengembangkan usahanya. Jika perusahaan menambah modal dengan menerbitkan saham maka sebagian dari laba bersih yang diperoleh akan digunakan untuk membayar dividen, sedangkan jika menggunakan utang maka berkewajiban untuk membayar bunga. Debt to Total Assets Ratio (DAR) merupakan salah satu rasio leverage yang dapat menggambarkan sejauh mana modal pemilik dapat menutupi utang kepada pihak luar. Semakin besar rasio ini akan semakin tidak menguntungkan bagi perusahaan karena tingkat ketergantungan perusahaan terhadap modal dari pihak luar semakin besar.

Debt to Total Assets Ratio (DAR) adalah salah satu rasio yang digunakan untuk mengukur tingkat solvabilitas perusahaan. Tingkat solvabilitas perusahaan adalah kemampuan perusahaan untuk membayar kewajiban jangka panjang yang dimiliki pihak perusahaan tersebut. Semakin tinggi rasio debt to Total Assets Ratio, semakin besar risiko keuangannya. Peningkatan risiko yang dimaksud adalah kemungkinan terjadinya gagal bayar karena perusahaan terlalu banyak menggunakan hutang.

\section{KAJIAN LITERATUR DAN HIPOTESIS}

Modal kerja merupakan bentuk investasi dari sebuah perusahaan terhadap aktiva-aktva jangka pendek kas, sekuritas, persediaan dan piutang. Perusahaan yang dapat dikatakan baik apabila perusahaan tersebut dapat memenuhi kewajiban-kewajiban perusahaan sehingga tidak perlu lagi melakukan peminjaman uang dari pihak lain seperti bank, dan perusahaan perlu meningkatkan kualitas dari produk atau hasil operasional kerja perusahaan tersebut. Dan membuat daya tarik para investor. agar tertarik menanamkan saham mereka sehingga perputaran modal kerja, kas, danpersediaan mengalami penigkatan atau atau profit (Fahmi, 2016) dalam Sapetu, Saerang \& Soepeno, (2017). 
Menurut Novita, Asri, and Sofie (2015), struktur modal juga merupakan bagian dari sumber pendanaan perusahaan yang dapat diperoleh dari modal ekuitas yang bersifat permanen dan sumber pendanaan jangka pendek bersifat sementara yang memiliki risiko lebih tinggi. Struktur modal adalah pendanaan ekuitas dan hutang pada suatu perusahaan yang sering dihitung berdasarkan besar atau relatifnya sumber pendanaan.

Struktur modal merupakan keputusan yang sangat penting bagi pihak perusahaan. Manajemen perusahaan dapat menentukan apakah akan menggunakan ekuitas atau utang jangka panjang dalam mengembangkan usahanya. yang mungkin timbul akibat berbagai situasi yang dihadapi perusahaan yang berkaitan dengan operasinya sehingga kajian variabel-variabel penelitian seperti modal kerja (yang akan dikaji dengan menggunakan current ratio, receivable turnover, dan net working capital), size dan struktur modal (yang akan dikaji dengan menggunakan debt to asset ratio) serta variabel dependentnya yakni return on assets.

Menurut Ginting \& Anggeresia (2015), current ratio tidak memiliki pengaruh secara parsial terhadap return on asset. Sementara menurut Holly (2016) telah menemukan adanya hubungan negatif antara Current Ratio dan profitabilitas atau return on asset. Sebaliknya, menurut Alavinasab dan Davoudi (2013), hubungan yang signifikan ditemukan antara Current Ratio dan return on asset (ROA).

Berdasarkan hasil penelitian yang telah diperoleh Wartono (2018), Net Working Capital Turnover memiliki pengaruh terhadap Return on Asset. secara parsial Net Working Capital Turnover tidak berpengaruh signifikan terhadap ROA. Menurut Dana, Made, and Susanti (2013), hasil uji statistik tidak memiliki pengaruh Net Working Capital Turnover terhadap Return On Total Assets.

Menurut Kusuma (2018), DAR tidak berpengaruh terhadap ROA perusahaan. Hasil ini tidak sesuai dengan hipotesis yang telah diajukan. Pengaruh tidak signifikan ini menunjukkan bahwa belum tentu perusahaan dengan rasio DAR yang tinggi menyebabkan profitabilitas perusahan (ROA) semakin rendah. Dimungkinkan perusahaan memiliki pendapatan yang lebih bervariasi sehingga dapat meningkatakan nilai profitabilitas perusahaan.

Prakoso \& Chabachib. (2015) yang menemukan bahwa ukuran perusahaan atau Size berpengaruh positif dan signifikan terhadap profitabilitas. Arah koefisien negatif menandakan bahwa peningkatan jumlah Total Asset, akan menyebabkan tingkat penurunan profitabilitas perusahaan.

\section{PENGEMBANGAN HIPOTESIS}

Menurut Ginting \& Anggeresia (2015), current ratio tidak memiliki pengaruh secara parsial terhadap return on asset. Sementara menurut Najoan, Holly. (2016) telah menemukan adanya hubungan negatif antara Current Ratio dan profitabilitas atau return on asset. Sebaliknya, menurut Alavinasab dan Davoudi (2013), hubungan yang signifikan ditemukan antara Current Ratio dan return on asset (ROA).

$\mathrm{H}_{1}$ : Current Ratio memiliki memiliki pengaruh yang bersignifikan dan Negatif terhadap Return on Assets (ROA).

Berdasarkan hasil penelitian yang telah diperoleh Wartono (2018), Net Working Capital Turnover memiliki pengaruh terhadap Return on Asset. Secara parsial, Working Capital Turnover tidak berpengaruh signifikan terhadap ROA. Menurut Dana, Made, dan Susanti (2013) hasil uji statistik tidak terdapat pengaruh Net Working Capital Level terhadap Return On Total Assets, maka:

$\mathrm{H}_{3}$ : Net Working Capital Turnover memiliki pengaruh yang signifikan dan positif terhadap Return on Assets (ROA).

Penelitian Sunarto dan Budi (2009) dalam Prakoso \& Chabachib (2015) menemukan bahwa ukuran perusahaan atau size berpengaruh positif dan signifikan terhadap profitabilitas. Arah koefisien negatif menandakan bahwa peningkatan jumlah Total Asset, akan menyebabkan penurunan profitabilitas perusahaan.

$\mathrm{H}_{3}$ : Size memiliki pengaruh yang signifikan positif terhadap Return on Assets (ROA).

Menurut Basri (2017), apabila rasionya tinggi, artinya pendanaan dengan utang semakin banyak, maka semakin sulit bagi perusahaan untuk memperoleh tambahan 
pinjaman karena dikhawatirkan perusahaan tidak mampu menutupi utang-utangnya dengan aktiva yang dimilikinya. Adapun hasil penelitian terdahulu oleh Kusumajaya (2011) dalam jurnal Kamal (2017) menyatakan bahwa tingkat perputaran Debt to Asset Ratio berpengaruh positif terhadap Return on Asset. Jika perusahaan memutuskan menetapkan struktur modal dalam jumlah yang besar, kemungkinan tingkat likuiditas akan terjaga namun kesempatan untuk memperoleh laba yang besar akan menurun yang pada akhirnya berdampak pada menurunnya profitabilitas.

$\mathrm{H}_{4}$ : Debt to Asset Ratio (DAR) memiliki pengaruh yang signifikan dan positif terhadap Return on Assets (ROA).

Penelitian ini dilakukan dengan tujuan untuk meramalkan pengaruh rasio profitabilitas yang terdiri dari current ratio, net working capital turnover, size dan debt to asset ratio terhadap return on asset dari perusahaan mabufaktur diberbagai sub sektor yang terdaftar di BEI. Untuk lebih jelasnya kerangka penelitian ini dapat ditunjukkan seperti pada Gambar 1 di bawah ini:

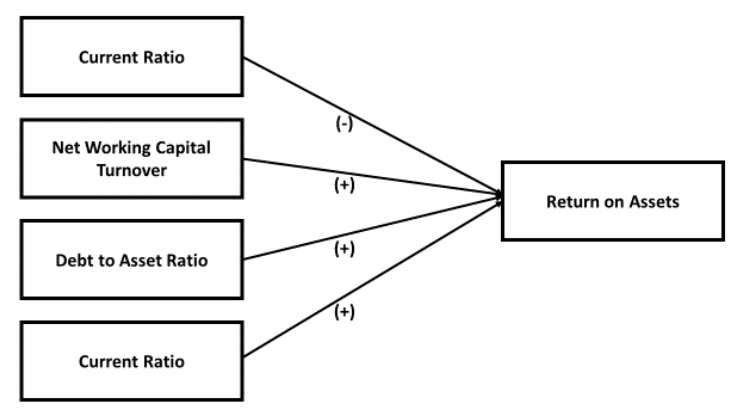

\section{Gambar 1. Kerangka Penelitian}

\section{METODE}

Populasi adalah jumlah dari keseluruhan kelompok individu, dan kejadian-kejadian yang menarik perhatian peneliti untuk diteliti atau diselidiki. Atau dengan kata lain, Populasi merupakan bentuk totalitas dari semua objek atau individu yang memiliki karakteristik yang tertentu jelas dan lengkap dari seluruh elemen yang berbentuk peristiwa, hal atau yang memiliki karakteristik yang serupa yang menjadi pusat perhatian seorang peneliti karena itu dipandang sebagai sebuah objek atau kelompok yang akan diteliti. Populasi dalam penelitian ini adalah 20 perusahaan manufaktur diberbagai sub sektor yang terdaftar diBursa Efek Indonesia pada tahun 2016-2018.
Sampel merupakan sebagian dari populasi yang diambil dengan cara tertentu dan memiliki karakteristik, jelas, dan lengkap hingga akan diselidiki dan dianggap dapat mewakili populasi. Maka dari itu dalam pengambilan data yang diperoleh diikuti sesuai kaidah ilmiah ini yang berfokus atau bertujuan mengetahui pengaruh keefektivitas modal, size, dan struktur modal terhadap return on assets dari laporan keuangan dari 20 perusahaan manufaktur diberbagai sub sektor yang terdaftar di BEI pada tahun 2016 sampai 2018 dengan sampel yang berupa laporan keuangan tahunan yang berakhir pada tanggal 31 Desember 2016 samapai 31 Desember 2018. Tehnik pengambilan sampel dalam penelitian, atau total sampel perusahaan manufaktur diberbagai sub sektor yang terdaftar di BEI yang akan analisis sebanyak 60 sampel dari 20 perusahaaan dikalikan dengan 3 periode laporan tahunan dari tiap-tiap perusahaan manufaktur diberbagai sub sektor yang terdaftar di BEI.

Kemudian dalam penelitian ini menggunakan purposive sampling, artinya bahwa populasi yang dijadikan sampel dalam penelitian ini adalah populasi yang memenuhi kriteria sampel tertentu sesuai yang dikehendaki peneliti.

Sesuai dengan judul penelitian yang diambil atau yang pilih penulis, yaitu "Analisis Efektivitas Modal Kerja, Size dan Struktur Modal Terhadap Return On Asset (ROA)”, maka, Pada penelitian ini terdapat dua variabel yaitu variabel terikat (dependent) dan variabel bebas (independent). Variabel terikat (Y) adalah Return on Assets sedangkan variabel bebas (X) terdiri dari Current Ratio, Net working capital Turnover, Size, dan Debt to asset ratio (DAR).

Variabel independen tersebut merupakan variabel yang dapat mempengaruhi atau yang menjadi sebab perubahannya atau timbulnya variabel terikat/variabel dependen. Sedangkan Variabel Dependen adalah variabel yang dipengaruhi atau yang menjadi akibat karena adanya variabel bebas. Sesuai dengan judul penelitian, bahwa maksud atau tujuan dalam penelitian ini adalah terkait dengan pengaruhnya keefektifiasan modal kerja, size, dan struktur modal terhadap Return On Assets (ROA) dari pihak perusahaan manufaktur dalam berbagai sub sektor pada tahun 2016 sampai 2018. 
Penentuan setiap variabel independen $(\mathrm{x})$ dan dependen (y) dapat dihitung sebagai berikut:

Tabel 1. Perhitungan Variabel Independen dan Dependen

\begin{tabular}{cc}
\hline Variabel & Ukuran \\
\hline Return on Assets & ROA= Net Profit / Total Sale $\times 100 \%$ \\
Current Ratio & Current Ratio $=$ Current Assets / Current Liability \\
Net Working Capital Turnover & Net Working Capital Turnover $=$ Total Credit Sale / Capital \\
Average & Size $=$ Ln total assets \\
Debt to asset ratio & Debt to asset ratio $=$ Total Hutang / Total Ekuitas
\end{tabular}

Jenis data yang digunakan dalam penelitian ini adalah data sekunder. Data sekunder merupakan data yang diperoleh melalui internet, jurnal, buku teks, atau berbagai media yang menyediakan tanpa perlu meminta langsung kepada perusahaan yang bersangkutan. Prosedur pengumpulan data yang dilakukan dalam penelitian ini adalah melalui dokumentasi yang diperoleh dari data sekunder.

\section{HASIL PENELITIAN}

Tabel 2. Statistik Deskriptif

\begin{tabular}{ccrrrrr}
\hline & N & Minimum & Maximum & \multicolumn{1}{c}{ Sum } & \multicolumn{1}{c}{ Mean } & Std. Deviation \\
\hline Current Ratio & 60 & .6703 & 38.980 & $1,46 \mathrm{E}+06$ & $2,43 \mathrm{E}+06$ & .6547816 \\
Net Working Capital & 60 & .2528 & 85.144 & 959.760 & $1,60 \mathrm{E}+06$ & 14.995 .874 \\
Size & 60 & -.9164 & 197.679 & $5,40 \mathrm{E}+06$ & $9,00 \mathrm{E}+06$ & 87.181 .518 \\
Debt Ratio & 60 & .0000 & 14.918 & 260.161 & .433601 & .1921253 \\
ROA & 60 & .004 & .227 & 4.884 & .08139 & .055002 \\
Valid N (listwise) & 60 & & & & & \\
\hline
\end{tabular}

Berdasarkan analisis statistik deskriptif pada Tabel 2 di atas, peneliti dapat mengambil kesimpulan bahwa:

a) Current Ratio terdapat nilai minimum sebesar 0,6703, sedangkan untuk nilai maksimum sebesar 3.8980 , nilai rata-rata dari Current Ratio pada perusahaan manufaktur dari berbagai sub sektor yang terdaftar di Bursa Efek Indonesia tahun 2016-2018 sebesar 2,43090467 dengan nilai standar deviasinya sebesar 0,6547816. Maka dapat diketahui bahwa nilai rata-rata lebih besar dari pada nilai standar deviasi dan hal ini menunjukkan bahwa data ukuran perusahaan bersifat homogen.

b) Net Working Capital terdapat nilai minimum sebesar 0,2528, sedangkan untuk nilai maksimum sebesar 8.5144, nilai rata-rata dari Net Working Capital pada perusahaan manufaktur dari berbagai sub sektor yang terdaftar di Bursa Efek
Indonesia tahun 2016-2018 sebesar 1.5996003 dengan nilai standar deviasinya sebesar 1.4995874 .

c) Size (In Sales) terdapat nilai minimum sebesar -0,9164, sedangkan untuk nilai maksimum sebesar 19,7679, nilai rata-rata dari Current Ratio pada pihak perusahaan manufaktur dari berbagai sub sektor yang terdaftar di Bursa Efek Indonesia tahun 2016-2018 sebesar 8,999976 dengan nilai standar deviasinya sebesar 8,7181518. Maka dapat diketahui bahwa nilai rata-rata lebih besar dari pada nilai standar deviasi dan hal ini menunjukkan bahwa data ukuran perusahaan bersifat homogen.

d) Debt to Asset Ratio terdapat nilai minimum sebesar 0,0000, sedangkan untuk nilai maksimum sebesar 1,4918, nilai rata-rata dari Debt to Asset Ratio Ratio pada perusahaan manufaktur di berbagai sub sektor yang terdaftar di Bursa Efek Indonesia tahun 2016-2018 sebesar 
0,433601 dengan nilai standar deviasinya sebesar 0,1921253. Maka dapat diketahui bahwa nilai rata-rata lebih besar dari pada nilai standar deviasi dan hal ini menunjukkan bahwa data ukuran perusahaan bersifat homogen.

e) Return On Assets terdapat nilai minimum sebesar 0,004 , sedangkan untuk nilai maksimum sebesar 0,227 , nilai rata-rata dari Return On Assets pada perusahaan manufaktur dari berbagai sub sektor yang terdaftar di Bursa Efek Indonesia tahun 2016-2018 sebesar 0,08139 dengan nilai standar deviasinya sebesar 0,055002. Maka dapat diketahui bahwa nilai rata-rata lebih besar dari pada nilai standar deviasi dan hal ini menunjukkan bahwa data ukuran perusahaan bersifat homogen.

Tabel 3. Uji Regresi Linier Berganda

\begin{tabular}{|c|c|c|c|c|c|c|c|}
\hline \multirow{2}{*}{ Model } & \multicolumn{2}{|c|}{$\begin{array}{l}\text { Unstandardized } \\
\text { Coefficients }\end{array}$} & \multirow{2}{*}{$\begin{array}{c}\text { Standardized } \\
\text { Coefficients } \\
\text { Beta }\end{array}$} & \multirow{2}{*}{ t } & \multirow{2}{*}{ Sig. } & \multicolumn{2}{|c|}{$\begin{array}{l}\text { Collinearity } \\
\text { Statistics }\end{array}$} \\
\hline & B & $\begin{array}{l}\text { Std. } \\
\text { Error }\end{array}$ & & & & Tolerance & VIF \\
\hline (Constant) & .116 & .058 & & 2.000 & .050 & & \\
\hline Current Ratio & -.169 & .080 & -.362 & -2.111 & .039 & 455 & 2.199 \\
\hline $\begin{array}{l}\text { Net Working } \\
\text { Capital }\end{array}$ & .011 & .005 & .307 & 2.422 & .019 & .835 & 1.197 \\
\hline Size & -.002 & .001 & -.343 & -2.826 & .007 & .911 & 1.097 \\
\hline $\begin{array}{l}\text { Debt Ratio } \\
\text { a. Dependent }\end{array}$ & $\mathrm{ROA}^{.013}$ & .052 & .045 & .244 & .809 & .402 & 2.490 \\
\hline
\end{tabular}

Berdasarkan hasil output SPSS 16.00 diatas dapat dilihat bahwa Current ratio memiliki sig. 0,039<0,05. untuk variabel variabel Net Working Capital memiliki sig. $0,019<0,05$. Dan untuk variabel Size (Ln sales) memiliki sig. 0,007<0,05. Serta untuk variabel Debt to Asset Ratio memiliki sig. 0,809 < 0,05. Dapat disimpulkan bahwa variabel return on assets dipengaruhi oleh variabel modal kerja (current ratio, receivable turnover, net working capital), dan size, terkecuali untuk struktur modal (debt to equit ratio) dikarenakan nilai signifikan yang diperoleh lebih dari 5\% $\hat{\mathrm{Y}}=0,116+-0,362 . \mathrm{CR}+0,307 . \mathrm{NWT}+-0,343$ .SIZE+ 0,045.DAR+5 + e

Kemudian, keputusan yang diambil dalam penganalisisan uji t adalah:

1. Apabila nilai sig. $<0,05$, atau $\mathrm{T}_{\text {hitung }}>\mathrm{T}_{\text {tabel }}$ maka memiliki pengaruh variabel $\mathrm{x}$ terhadap variabel y

2. Apabila nilai sig $>0,05$, atau $\mathrm{T}_{\text {hitung }}<\mathrm{T}_{\text {tabel }}$ maka tidak memiliki pengaruh variabel $\mathrm{x}$ terhadap variabel y

$\mathrm{T}$ tabel $=\mathrm{t}(\mathrm{a} / 2 ; \mathrm{n}-\mathrm{k}-1)=\mathrm{t}(0,025 ; 55)=$ 1,67303

Kemudian, keputusan yang diambil ddalam penganalisisan uji $\mathrm{f}$ adalah:

3. Apabila nilai sig. $<0,05$, atau $\mathrm{F}_{\text {hitung }}>\mathrm{F}_{\text {tabel }}$ tabel maka memiliki pengaruh variabel $\mathrm{x}$ secara simultan terhadap variabel y
4. Apabila nilai sig $>0,05$, atau $\mathrm{F}_{\text {hitung }}<\mathrm{F}_{\text {tabel }}$ maka tidak memiliki pengaruh variabel $\mathrm{x}$ secara simultan terhadap variabel $\mathrm{y}$.

$\mathrm{F}$ tabel $=\mathrm{F}(\mathrm{k} ; \mathrm{n}-\mathrm{k})=\mathrm{F}(4 ; 56)=2,54$

\section{PEMBAHASAN}

Hasil pengujian $\mathrm{H} 1$ terdukung atau sesuai dari hasil penelitian terdahulu karena hasil yang didapatkan bahwa variabel Current ratio berpengaruh terhadap return on assets. hal ini menunjukkan bahwa nilai $\mathrm{T}_{\text {hitung }}>\mathrm{T}_{\text {tabel }}$ $2.111<1,67303$ memiliki signifikan 0,039< 0,05 dan coefficient $\beta-0,362$ dengan arah negatif. Dengan demikian dapat kita simpulkan bahwa nilai $T_{\text {hitung }}$ berada dikawasan area yang berpengaruh negatif atau diluar batas ha, ataupun $\mathrm{H} 1$ dalam penelitian variabel current ratio diterima dan H0 di tolak. Dan pada nilai signifikansi, variabel current ratio lebih kurang dari 5\% Artinya, variabel current ratio memiliki pengaruh signifikan terhadap return on assets.

Hasil pengujian $\mathrm{H} 2$ terdukung atau sesuai dari hasil penelitian terdahulu karenai hasil yang didapatkan bahwa variabel Net working capital menunjukkan bahwa nilai $\mathrm{T}_{\text {hitung }}>\mathrm{T}_{\text {tabel }} 2,422<1,67303$ memiliki signifikan $0,019<0,005$ dan coefficient $\beta 0,307$ dengan arah positif. Dengan demikian dapat kita simpulkan bahwa nilai $T_{\text {hitung }}$ berada dikawasan area yang berpengaruh negatif atau diluar batas ha, ataupun H1 dalam penelitian 
variabel Net working capital diterima dan $\mathrm{H} 0$ di tolak. Dan pada nilai signifikansi, variabel $\mathrm{Net}$ working capital lebih kurang dari 5\% Artinya, variabel Net working capital memiliki pengaruh signifikan terhadap return on assets.

Hasil pengujian $\mathrm{H} 3$ tidak terdukung atau tidak sesuai dari hasil penelitian terdahulu karenai hasil yang didapatkan bahwa variabel Size berpengaruh negatif terhadap return on assets. hal ini menunjukkan bahwa nilai $\mathrm{T}_{\text {hitung }}$ $>\mathrm{T}_{\text {tabel }}-2,826>1,67303$ memiliki signifikan $0,007>0,05$ dan coefficient $\beta-0,343$ dengan arah yang negatif. Dengan demikian dapat kita simpulkan bahwa nilai $\mathrm{T}_{\text {hitung }}$ berada dikawasan area yang berpengaruh negatif atau diluar batas ha, ataupun $\mathrm{H} 1$ dalam penelitian variabel Size diterima dan H0 di tolak. Dan pada nilai signifikansi, variabel Size lebih kurang dari 5\% Artinya, variabel Size memiliki pengaruh signifikan terhadap return on assets.

Hasil pengujian $\mathrm{H} 4$ tidak terdukung atau tidak sesuai dari hasil penelitian terdahulu karenai hasil yang didapatkan bahwa variabel Debt to asset ratio menunjukkan bahwa nilai $\mathrm{T}_{\text {hitung }}>\mathrm{T}_{\text {tabel }} 0,244<1,67303$ memiliki signifikan $0,809>0,005$ dan coefficient $\beta$ 0,045 dengan arah positif. Dengan demikian dapat kita katakan bahwa nilai $\mathrm{T}_{\text {hitung }}$ berada dikawasan area yang berpengaruh positif atau diluar batas ha, sehingga dapat disimpulkan ho dalam penelitian variabel size diterima. Artinya, variabel Debt to asset ratio tidak memiliki pengaruh terhadap return on assets. Dengan demikian dapat kita simpulkan bahwa nilai $\mathrm{T}_{\text {hitung }}$ berada dikawasan area yang berpengaruh negatif atau diluar batas ha, ataupun $\mathrm{H} 1$ dalam penelitian variabel Debt to asset ratio ditolak dan $\mathrm{H} 0$ di terima. Dan pada nilai signifikansi, variabel current ratio lebih dari 5\% Artinya, variabel current ratio tidak memiliki pengaruh signifikan terhadap return on assets.

\section{SIMPULAN, KETERBATASAN, DAN SARAN}

\section{Simpulan}

Berdasarkan dari hasil penelitian dan pembahasan yang telah dikajikan, dapat ditarik kesimpulan sebagai berikut:

1. Current Ratio berpengaruh terhadap Return On Assets. hal ini dapat dijelaskan bahwa semakin tinggi rasio lancar memungkinkan dapat membantu pengembalian assets yang digunakan perusahaan dalam menjalankan usahanya. Seperti hasil pengujiannya bahwa dikatakan, Current ratio berpengaruh negatif terhadap return on assets. hal ini menunjukkan bahwa nilai $\mathrm{T}_{\text {hitung }}>\mathrm{T}_{\text {tabel }}$ $2.111<1,67303$ memiliki signifikan 0,039 $<0,05$ dan coefficient $\beta-0,362$ dengan arah negatif. Dengan demikian dapat kita katakan bahwa variabel current ratio memiliki pengaruh terhadap return on assets.

2. Net working capital berpengaruh terhadap Return On Assets. hal ini dapat dijelaskan bahwa semakin tinggi rasio lancar memungkinkan dapat membantu pengembalian assets yang digunakan perusahaan dalam menjalankan usahanya. Seperti hasil pengujiannya bahwa dikatakan, Net working capital menunjukkan bahwa nilai $\mathrm{T}_{\text {hitung }}>\mathrm{T}_{\text {tabel }}$ $2,422<1,67303$ memiliki signifikan 0 , $019<0,005$ dan coefficient $\beta$ 0,307 dengan arah positif. Dengan demikian dapat kita katakan bahwa variabel Net working capital memiliki pengaruh terhadap return on assets.

3. size berpengaruh terhadap Return On Assets. hal ini dapat dijelaskan bahwa semakin tinggi rasio lancar memungkinkan dapat membantu pengembalian assets yang digunakan perusahaan dalam menjalankan usahanya. Seperti hasil pengujiannya bahwa dikatakan, size berpengaruh negatif terhadap return on assets. hal ini menunjukkan bahwa nilai $\mathrm{T}_{\text {hitung }}>\mathrm{T}_{\text {tabel }}$ 2,826 > 1,67303 memiliki signifikan 0,007 $>0,05$ dan coefficient $\beta-0,343$ dengan arah yang negatif. Dengan demikian dapat kita katakan bahwa variabel size tidak memiliki pengaruh terhadap return on assets.

4. Debt to asset ratio berpengaruh terhadap Return On Assets. hal ini dapat dijelaskan bahwa semakin tinggi rasio lancar memungkinkan dapat membantu pengembalian assets yang digunakan perusahaan dalam menjalankan usahanya. Seperti hasil pengujiannya bahwa dikatakan, Debt to asset ratio menunjukkan bahwa nilai $\mathrm{T}_{\text {hitung }}>\mathrm{T}_{\text {tabel }}$ 
0,244 < 1,67303 memiliki signifikan 0,809 $>0,005$ dan coefficient $\beta$ 0,045 dengan arah positif. Dengan demikian dapat kita katakan bahwa variabel Debt to asset ratio memiliki pengaruh terhadap return on assets.

\section{Keterbatasan Penelitian}

Penelitian ini telah diusahakan dan di laksanakan sesuai dengan prosedur ilmiah, akan tetapi masih memiliki keterbatasan, yaitu:

1. Jumlah populasi yang masih sedikit dikarenakan hasil report dari perusahaan yang diambil dan dianalisis mengggunakan SPSS menghasilkan output data normalitas hanya sebanyak 20 perusahaan dari semua perusahaan manufaktur yang terdaftar di BEI.

2. Adanya keterbatasan penelitian dalam memasukan variabel. Seperti halnya memiliki variabel yang mempunyai teknikal yang sama sehingga dalam proses penganalisisan menggunakan spss ada salah satu variabel yang tidak muncul contohnya variabel Receivable Turnover. Karena memiliki teknik analisis yang sama dengan Net Working Capital.

\section{Saran}

1. Bagi perusahaan, perusahaan perlu meningkatkan kembali daya kinerja atau kinerja keuangan agar perusahaan dapat meningkatkan hasil kinerja perusahaan yang maksimal dalam memperoleh profitability yang tinggi hingga mampu mengembalikan asset kembali dan dapat beroperasi kembali dengan menggunakan biaya secara efektif dan efisien.

2. Bagi Investor, sebelum mengambil keputusan dalam berinvestasi alangkah baiknya memperhatikan kemampuan modal kerja tingkat penjualan atau struktur modal dari setiap laporan keuangan perusahaan dengan memperhatikan rasio lancar, perputaran modal, tingkat penjualan, dan pengembalian piutang sebagai referensi dalam pengambilan suatu keputusan investasi. Karena variabelvariabel tersebut memiliki pengaruh yang signifikan terhadap return on assets.

3. Bagi penelitian selanjutnya, sebaiknya melakukan pengkajian dengan melihat data yang sejajar atau tidak mengambil profitability yang sangat tinggi dari perusahaan lain agar dalam penganalisissan menggunakan SPSS khususnya SPSS 16.00 menghasilkan data yang akurat atau normal. Kemudian, dapat menambahkan lagi variabel penelitian, periode waktu, dan memperbanyak sampel sampel penelitiannya.

\section{REFERENSI}

Andy Kridasusila, Windasari Rachmawati Abstrak. 2016. Analisis Pengaruh Current Ratio , Inventory Turn Over dan Debt to Equity Ratio pada Perusahaan Otomotif dan Produk Komponennya Pada Bursa Efek Indonesia (2010 2013) Andy Kridasusila, Windasari Rachmawati.” 18, 7-22.

Astutik, Endang Fuji, and Ammelia Novita Anggraeny. 2019. Pengaruh Current Ratio (CR) Dan Debt To Asset Ratio (DAR) Terhadap Return On Asset (ROA) Pada PT. Indocement Tunggal Prakarsa Tbk Periode 2008-2017. Jurnal SEKURITAS (Saham, Ekonomi, Keuangan dan Investasi), 3(1): 97.

Damayanti, Pupik, and Dhian Andanarini Minarsavitri. 2012. Analisis Pengaruh Ukuran (Size), Capital Adequacy Ratio (CAR), Pertumbuhan Deposit, Loan to Deposit Ratio (LDR), terhadap Profitabilitas Perbankan Go Public Di Indonesia Tahun 2005-2009 (Studi Empiris Perusahaan Perbanka Yang Terdaftar Di BEI). Jurnal Ilmiah Manajemen dan Akuntansi Terapan (JIMAT), 3(2): 45-54.

Dana, Made, and Jeni Susanti. 2013. Hubungan Efficiency Level Working Capital Management dengan Return on Total Assets. Jurnal Ekonomi dan Bisnis, 12(1): 45-54.

Gerungai, Feibi Teresa Budiang, Sifrid S. Pangemanan, Natalia Y. T. 2017. Pengaruh Perputaran Total Aset, Perputaran Piutang dan Perputaran Persediaan terhadap ROA pada Perusahaan Sub Sektor Perdagangan Eceran yang Terdaftar di BEI. Jurnal EMBA: Jurnal Riset Ekonomi, Manajemen, Bisnis dan Akuntansi, 5(2): 1956-66. 
Ginting, Wenny Anggeresia. 2015. Analisis Pengaruh Current Ratio, Working Capital Turnover, Dan Total Asset Turnover terhadap Return On Asset. 8.

Gresela Patresia Sihotang, Emi Christin br. Ginting 2019. Pengaruh Current Ratio, Debt to Equity Ratio Dan Working Capital Turnover terhadap Return On Asset pada PT. Perkebunan Nusantara III Periode 2015-2017. 3: 1-10.

Herlina Yesi. 2012. Pengaruh Current Ratio, Net Working Capital Turnover dan Debt to Asset Ratio terhadap ROA pada Perusahaan Property dan Real Estate yang Terdaftar di Bursa Efek Indonesia Periode 2008-2012 Herlina. 109(4): 555-62.

Kamal, M Basri. 2017. Pengaruh Receivable Turn Over dan Debt to Asset Ratio (DAR) terhadap Return On Asset (ROA) pada Perusahaan Pertanian yang Terdaftar di Bursa Efek Indonesia (BEI). Jurnal Ilmiah Manajemen dan Bisnis, 17(2): 68-81.

Kurnia, Indra, and Wisnu Mawardi. 2012. Analisis Pengaruh Bopo, EAE, LAR dan Firm Size terhadap Kinerja Keuangan (Studi Kasus Pada Bank Umum Konvensional yang Terdaftar Di Bursa Efek Indonesia Periode 2008-2011).” Diponegoro Journal of Management, 1(4): 49-57.

Kunarsih, Rita Andini, and Agus Suprijanto. 2018. Pengaruh NIM, NPL DAN LDR Terhadap Kinerja Keuangan (ROA) Dengan CAR Sebagai Variabel Intervening (Studi Kasus Bank BUMN yang Terdaftar di BEI Periode Tahun 2012-2016).” Journal of Accounting, 20, 1-19.

Kusuma, Robi Pramana. 2018. Pengaruh DAR, Ukuran Perusahaan, Risiko, Pajak, Dan Likuiditas Terhadap Profitabilitas Perusahaan Sektor Pertambangan Di Indonesia. BISMA (Bisnis dan Manajemen), 8(2), 191.
M.Thoyib, Firmansyah, Darul Amri, Riza Wahyud, Melin M.A. 2018. Pengaruh Current Ratio, Debt to Asset Ratio, Debt to Equity Ratio dan Total Asset Turnover Terhadap Return on Assets Pada Perusahaan Properti dan Real Estate Di Bursa Efek Indonesia. 4(2), 10-23.

Najoan, Holly. 2016. Analisis Kinerja Perbankan Ditinjau dari Aspek Profitabilitas dan Efisiensi (Studi Kasus Pada Bank yang Terdaftar Di Bursa Efek Indonesia Periode 2012- 2014). Jurnal Riset Bisnis dan Manajemen UNSRAT, 4(3), 407-20.

Novita, Bunga Asri, and Sofie. 2015. Pengaruh Struktur Modal dan Likuiditas terhadap Profitabilitas. 13-28.

Prio Galih Raga Prakoso, Mochammad Chabachib. 2015. Analisis Pengaruh Current Ratio, Size, Debt to Equity Ratio, dan Total Asset Turnover yerhadap Dividend Yield dengan Return on Asset Sebagai Variabel Intervening. Diponegoro Journal of Marketing, 5(2): 2337-3814.

Putry, Nur Anita Chandra Putry, and Teguh Erawati. 2013. Pengaruh Current Ratio, Total Assets Turnover, dan Net Profit Margin, terhadap Return On Assets.

PA, Mahardhika, and Dohar Marbun. 2016. Pengaruh Current Ratio dan Debt to Equity Ratio Terhadap Return on Assets. Widyakala Journal, 3, 23.

Ramantha, A.A. Yogi Prasanjaya I Wayan. 2013. Analisis Pengaruh Rasio Car, Bopo, LDR Dan Ukuran Perusahaan Terhadap Profitabilitas Bank yang Terdaftar Di BEI. E-Jurnal Akuntansi, 4(1), 230-45.

Rahayu, S R I et al. 2016. Pengaruh Current Ratio, Net Working Capital Turnover, Dan Debt to Asset Ratio terhadap ROA pada Perusahaan Property dan Real Estate yang Terdaftar di Bursa Efek Indonesia Periode 2012-2014. 
Supatmin. 2017. Pengaruh Net Working Capital Dan Current Ratio Terhadap Return On Assets (Studi Kasus Pada PT. Indah Kiat Pulp and Paper Tbk di Tangerang). 1(2), 128-44.

Supardi, Herman, and H Suratno. 2016. "Pengaruh Current Ratio, Debt to Asset Ratio, Total Asset Turnover dan Inflasi Terhadap Return on Asset." Jurnal Ilmiah Akuntansi Fakultas Ekonomi, 2, 16-27.

Sutanto, J E. 2012. Efficiency of Working Capital on Company Profitability in Generating Roa (Case Studies in CV. Tools Box in Surabaya). 15(110), 289304.

Setiawan, Elyas, and 2015. Pengaruh Current Ratio, Inventory Turnover, Debt to Equity Ratio, Total Asset Turnover, Sales, dan Firm Size terhadap ROA Pada Perusahaan Food and Beverage yang Terdaftar Di Bursa Efek Indonesia (Bei) Periode 2010-2013. 151, 10-17.

Susilowibowo, Eka Ayu Rahayu dan Joni, dan 2014. 2013. Pengaruh Perputaran Kas, Perputaran Piutang dan Perputaran Persediaan terhadap Profitabilitas Perusahaan Manufaktur. Jurnal Ilmu Manajemen, 2(4): 1444-55.

Taufiqurrohman, Cecep, and Siska Agnestia. 2017. Pengaruh Working Capital Turn Over dan Current Ratio terhadap Return on Asset pada Perusahaan Farmasi. 6(12): 22-32.

Tyas, Eria Pratikaning. 2019. Pengaruh Current Ratio, Total Asset Turn Over, dan Net Profit Margin terhadap Return on Asset pada Perusahaan Subsektor Makanan dan Minuman yang Terdaftar Di BEI pada Tahun 2012-2016. Journal of Chemical Information and Modeling, 53(9), 1689-1699.

M.Thoyib, Firmansyah, Darul Amri, Riza Wahyud, Melin M.A. 2018. Pengaruh Current Ratio, Debt to Asset Ratio, Debt to Equity Ratio dan Total Asset Turnover Terhadap Return on Assets pada
Perusahaan Properti dan Real Estate di Bursa Efek Indonesia. 4(2), 10-23.

Wijaya, Linda Vania, and Lauw Tjun Tjun. 2018. Pengaruh Cash Turnover, Receivable Turnover, dan Inventory Turnover terhadap Return on Asset Perusahaan Sektor Makanan dan Minuman yang Terdaftar di Bursa Efek Indonesia Periode 2013-2015. Jurnal Akuntansi Maranatha, 9(1): 74-82.

Wartono, Tri. 2018. Pengaruh Current Ratio (CR) Dan Debt to Equity Ratio (DER) Terhadap Return On Asset (ROA) (Studi Pada PT Astra International, Tbk). 6(2).

Widiyanti, Marlina, And Samadi W Bakar. 2014. "Pengaruh Working Capital Turnover, Cash Turnover, Inventory Turnover Dan Current Ratio Terhadap Profitabilitas (Roa) Perusahaan Property Dan Real Estate Yang Terdaftar Di Bei.” Jurnal Manajemen dan Bisnis Sriwijaya, 12(2), 111-26.

Willi, Nia, and Stefani Chandra. 2019. Effect of CR, DAR, TATO and Tangibility on ROA in Manufacturing Companies Listed On Indonesia Stock Exchange. Bilancia Jurnal Ilmiah Akuntansi, 3(1): 91-98.

Yuliani, Rina. 2013. Pengaruh Perputaran Piutang terhadap Profitabilitas pada Perusahaan PT. Unilever Indonesia Tbk. Thun 2005-2012.” Jurnal Ilmiah Mahasiswa FEB. 
JRAK, Volume 16, No.2 Agustus 2020 
JRAK, Volume 16, No.2 Agustus 2020 
